American Journal of Environmental Sciences 4 (6): 649-653, 2008

ISSN $1553-345 \mathrm{X}$

(C) 2008 Science Publications

\title{
Organochlorine Pesticide Residues in Fish Samples from Lagos Lagoon, Nigeria
}

\author{
${ }^{1}$ David Adeyemi, ${ }^{1}$ Grace Ukpo, ${ }^{1}$ Chimezie Anyakora and ${ }^{2}$ JohnPaul Unyimadu \\ ${ }^{1}$ Department of Pharmaceutical Chemistry, University of Lagos, Nigeria \\ ${ }^{2}$ Nigerian Institute of Oceanography and Marine Research, Nigeria
}

\begin{abstract}
The organochlorine pesticide (OCPs) residues were measured in three species of fish Tilapia zilli (Red belly Tilapia), Ethmalosa fimbriata (Bonga Shad) and Chrysichthys nigrodigitatus (Catfish). These fish species are a significant part of the diet of residents of Lagos Nigeria. The organochlorine pesticides analyzed include DDT(pp'1,1,1-trichloro-2,2-bis-(4-chlorophenyl) ethane), DDD, DDE (pp 1,1-dichloro-2, 2-bis-(4-chlorophenyl) ethylene, $\mathrm{HCH}$ (gamma 1,2,3,4,5,6-hexachlorocylohexane, HCB (hexachlorobenzene),Dieldrin (1,2,3,4,10,10-hexachloro-6,7-epoxy-1,4,4a, 5,6,7,8,8a octahydro$1,4,5,8$ dimethanonaphthalene) and transnonachlor. The analysis was done using Gas Chromatograph with Electron Capture Detector. The mean concentration of OCPs ranged from 0.01-8.92 ppm. The concentration of the OCPs (except for HCHs) in fish samples in this study were below the extraneous residue limit of $5 \mathrm{ppm}$, set by the codex alimentarious commission of FAO-WHO-1997. However, the concentrations were higher than those detected during previous studies of fish samples from Lake Victoria, Uganda in Africa. Also the levels were quite high when compared with the allowable Federal Environmental Protection Agency (FEPA), now Federal Ministry of Environment limit and can be harmful if the trend is not checked. The study also showed that concentration of OCPs were higher in adult, than in Juvenile of most of the fish and there was no correlation observed between fat content and total concentration of OCPs.
\end{abstract}

Key words: Organochlorine pesticide, fish, Lagos lagoon, GC-ECD

\section{INTRODUCTION}

Organochlorine Pesticides (OCPs) are a class of non polar toxic chemical compounds classified as dichlorodiphenylethane cyclodienes and chlorinated benzenes ${ }^{[1]}$. OCPs are ubiquitous environmental contaminant which have spread globally and have been detected in foodstuffs, drinking water, sediments as well as wide range of biota including fish ${ }^{[2-4]}$.

Numerous studies on both human and laboratory animals provide strong evidence of the toxic potential of exposure to OCPs. The health effects associated with OCPs include reproductive failures, birth defect, endocrine disruption immune system dysfunction and cancer ${ }^{[5-8]}$. Studies also revealed that OCPs have strong potential to cross placental barriers even in minute concentration and cause serious neonatal damage ${ }^{[9]}$. This led to a ban on the use of these compounds in 1970. However, the continued use of OCPs in developing countries is of international concern because of their persistence and ability to undergo long distance atmospheric transport ${ }^{[10]}$ and eventually getting deposited in areas far from the point of application, this also led government and researchers to be concerned with their presence in the environment.

Most of the pesticides that have been used extensively for long periods in Nigeria are OCPs, the high efficacy and lower cost of OCPs compared with alternative pesticides is the reason for their continued use in Nigeria ${ }^{[11]}$. The OCPs are widely used in Agriculture, as well as in mosquito and tsetse fly control.

Nigeria's vast water resources especially the Lagos lagoon are among those most affected by environmental stress imposed by human population growth, anthropogenic activities in agriculture and industrialization, the disposal and management of waste in Lagos, Nigeria present serious environmental problems as the usual methods of waste disposal such as land filling, dumping site and incineration leads to contamination of underground and surface water bodies and resulting in accumulation of the chemicals in edible zooplanktons, including fish. However, not much work has been done in this regard here in Nigeria, as limited data are available ${ }^{[2,12,13]}$. 
In previous research, mean concentration of OCPs in fish samples from rivers in Edo State, Nigeria ranged from 0.36-0.71 ppb while the mean concentration of OCPs in fish samples from Ogun river (inflow location of the Lagos lagoon) ranged from $0.06-1.98 \mathrm{ppb}^{[2,14]}$. The overall consumption of fish is on a steady increase all over the world, including Nigeria, as it is a readily available cheap source of protein and easily digested in the gastrointestinal tract ${ }^{[15]}$. The fish species analyzed in this work are widely consumed by Nigerians hence the study may help to evaluate the health risk residue levels of OCPs detected in fish poses on the population.

\section{MATERIALS AND METHODS}

Sampling area: Lagos is a densely populated (with more than 12 million people) city in Nigeria. Lagos lagoon is about $50 \mathrm{~km}$ long and $3-13 \mathrm{~km}$ wide, separated from Atlantic Ocean by long sand and spit 2$5 \mathrm{~km}$ wide with swampy margins on the Lagoon side. Lagos Lagoon empties into the Atlantic via Lagos Harbor, a main channel through the heart of the city, $0.25-1 \mathrm{~km}$ wide and $10 \mathrm{~km}$ long. The principal ocean port of Lagos is located at Apapa in a broad western branch off the main channel of the harbor. Lagos Lagoon is fairly shallow and the city spread along more than $30 \mathrm{~km}$ of the Lagoon's south western and western shoreline. The $11 \mathrm{~km}$ long 3rd mainland bridge was built off the western shore to bypass congested mainland suburbs. The area west of the lagoon is not well provided with road and many communities there traditionally relied on water transport. The pollution of the lagoon by urban and industrial waste is major problems as the large population depends on it, for potable and recreational water, as well as a source of cheap and affordable protein in form of fish.

Sampling: Different fish species were collected in July 2007, during a fishing tour of the Lagos lagoon. The fish species were collected alive from their normal environment, martyred and stored in an ice container before transporting to the laboratory where they were stored at temperature of $-20^{\circ} \mathrm{C}$ until ready for use. The fish species were Tilapia zilli (Tilapia), Ethmalosa Fimbriata (Bonga shad) and chrysichthys nigrodigitatus (Catfish). They were identified by Nigerian institute of Oceanography and Marine Research (Table 1).

Reagents: All chemicals and reagents were of analytical grade and of highest purity possible. LC grade dichloromethane and n-hexane used for the extraction and clean up were obtained from Fisher Scientific. The silica gel used for the clean up was supplied by BDH laboratories. The acetone and anhydrous sodium sulphate used in this study were also obtained from $\mathrm{BDH}$ laboratories. A mixture of OCPs, DDT and derivatives $(\mathrm{HCH}, \mathrm{HCB}$, dieldrin, DDD, DDE and transnonachlor) were obtained from Sigma Aldrich

Extraction: Prior to extraction, the fish specimens were dissected and the muscle tissue removed. $10 \mathrm{~g}$ of muscle tissue was ground with anhydrous sodium sulphate until completely dry homogenate was obtained $^{[16]}$. Extraction was carried out with dichloromethane in a cold extraction mode ${ }^{[17]}$. After the extraction, the extracting solvent was evaporated using a rotary evaporator and the mass of the extractable fat determined by gravimetry.

Sample clean up: The isolation of OCPs from the lipid matrix was done by solid phase extraction in a normal phase mode. Activated silica gel was loaded unto a glass chromatographic column (i.d $20 \mathrm{~mm}$, height, $400 \mathrm{~mm}$ ) and conditioned with dichloromethane. The extractable fats from the samples were dissolved in $5 \mathrm{~mL}$ n-hexane and loaded on to the column and eluted with about $60 \mathrm{~mL}$ n-hexane. The eluents were then concentrated using a rotary evaporator and under a gentle stream of pure Nitrogen. The samples were thereafter dissolved in $1 \mathrm{ml}$ acetone and ready for GC analysis.

Gas chromatography: Analyses were performed with Perkin-model 5890 Gas chromatography equipped with Ni 63 electron capture detector. A low polar HP-5 column of $30 \mathrm{~m}$ length, $0.32 \mathrm{~mm}$ i.d and 0.25 um film thickness was used. Nitrogen was used as a carrier gas at a flow rate $40 \mathrm{~mL} \mathrm{sec}{ }^{-1}$. Data were processed using an HP 3396 integrator. The operating parameters were as follows: Injector temperature set at 250 and $300^{\circ} \mathrm{C}$ for the detector, the oven temperature was programmed at $150^{\circ} \mathrm{C}$ initially (5 min hold) and increased to $300^{\circ} \mathrm{C}$ at $4^{\circ} \mathrm{C} \mathrm{min}{ }^{-1}$ to give the analysis period of $34 \mathrm{~min}$.

Identification and quantification: The standard mixture contained OCPs, DDT derivatives, $\mathrm{HCH}, \mathrm{HCB}$, dieldrin, DDD, DDE and transnonachlor. Quantification was done based on area count match with those of known concentration of the standards.

\section{RESULTS AND DISCUSSION}

Prior to the analysis the recovery studies were carried out using Decaflourobiphenyls and found to range between 78 and $80 \%$. The linearity of response was ascertained using standard mixture of OCPs and it 
Am. J. Environ. Sci., 4 (6): 649-653, 2008

Table 1: Parameters of fish species

\begin{tabular}{lllll}
\hline $\begin{array}{l}\text { Fish species common } \\
\text { names in bracket }\end{array}$ & $\begin{array}{l}\text { Average } \\
\text { size }(\mathrm{cm})\end{array}$ & $\begin{array}{l}\text { Average } \\
\text { weight }(\mathrm{g})\end{array}$ & $\begin{array}{l}\text { Mean concentration } \\
\text { of lipid per wet weight } \mathrm{g} \mathrm{kg}^{-1}\end{array}$ & $\begin{array}{l}\text { Mean concentration of } \\
\mathrm{OCPs}_{\text {per wet weight Mg kg}}{ }^{-1}\end{array}$ \\
\hline 1. Tilapia zilli Juvenile (red belly Tilapia) & 11.70 & 29.40 & 4.20 & 8.07 \\
2. Tilapia zilli Adult (red belly Tilapia) & 16.60 & 91.40 & 12.30 & 20.57 \\
3. Ethmalosa fimbriata Juvenile (Bonga shad) & 11.70 & 13.70 & 20.40 & 2.72 \\
4. Ethmalosa fimbriata adult (Bonga shad) & 20.70 & 80.40 & 6.10 & 19.05 \\
5. Chrysichthys nigrodigitatus Juvenile (catfish) & 14.60 & 19.70 & 4.60 & 4.92 \\
6. Chrysichthys nigrodigitatus Adult (catfish) & 45.00 & 927.20 & 13.80 & 4.13 \\
\hline
\end{tabular}

Table 2: Mean concentration of OCPs in fish species ( $\mathrm{mg} \mathrm{kg}^{-1}$ wet weight)

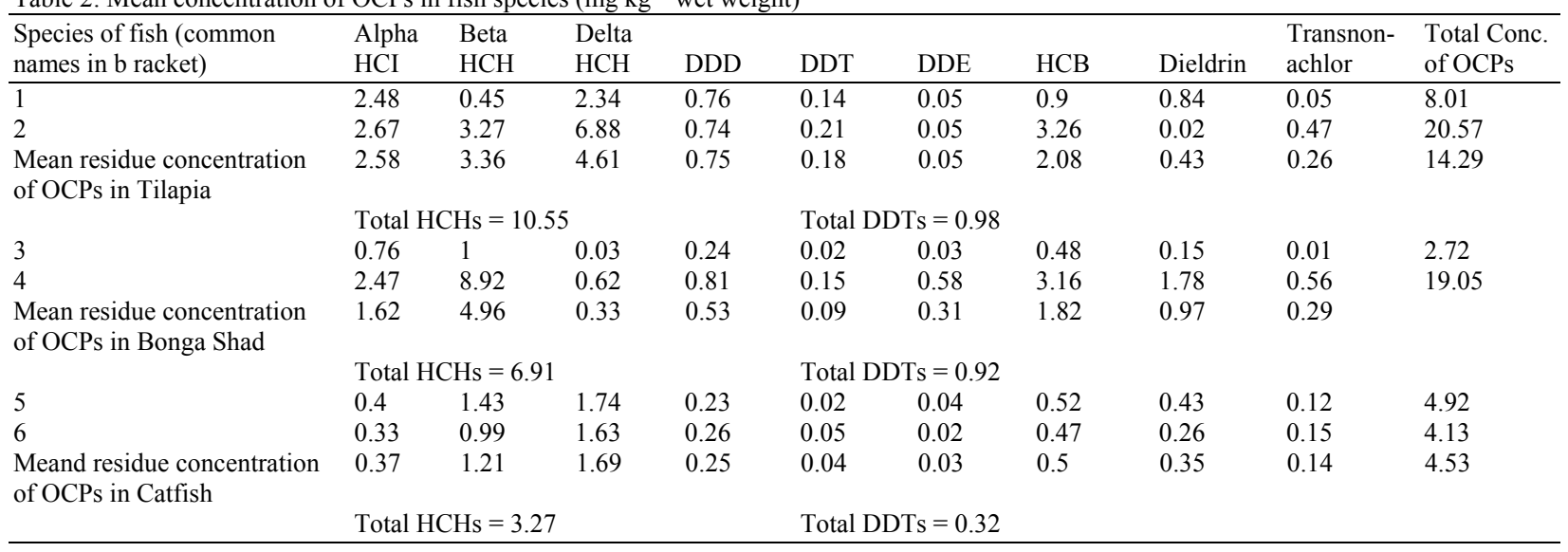

Table 3: Mean concentration of OCPs in fish species $\mathrm{m} \mathrm{kg}^{-1}$ lipid weight

\begin{tabular}{llllllllll}
\hline Fish species common names in bracket & HCB & Alpha HCH & Beta HCH & Delta HCH & DDD & DDT & DDE & Dieldrin & Transnonachlor \\
\hline Tilapia zilli Juvenile (red belly Tilapia) & 214.5 & 591.0 & 106.9 & 556.4 & 181.7 & 33.9 & 10.7 & 199.6 & 12.1 \\
Tilapia zilli Adult (red belly Tilapia) & 265.2 & 217.1 & 509.4 & 559.0 & 60.3 & 16.8 & 4.1 & 1.3 & 38.3 \\
Ethmalosa fimbriata Juvenile (Bonga shad) & 23.4 & 37.3 & 49.3 & 1.4 & 60.9 & 0.7 & 1.4 & 7.4 & 0.6 \\
Ethmalosa fimbriata adult (Bonga shad) & 512.3 & 403.8 & 145.8 & 101.5 & 131.7 & 24.2 & 95.0 & 291.1 & 92.1 \\
Chrysichthys nigrodigitatus Juvenile (eatfish) & 112.8 & 95.3 & 308.9 & 376.2 & 49.1 & 4.6 & 7.8 & 92.4 & 26.4 \\
Chrysichthys nigrodigitatus Adult (eatfish & 34.4 & 24.0 & 71.6 & 118.2 & 17.3 & 3.5 & 1.1 & 18.6 & 11.1 \\
\hline
\end{tabular}

ranged from 0.945-0.994. The relative standard deviation was less than $7 \%$. Table 2 shows the mean concentration of OCPs in fish species per wet weight while table 3 shows the concentration per lipid weight. Figure 1 and 2 show these in a more graphic way. The amount of lipid per wet weight seems to follow no specific pattern in the fish samples. In Tilapia and Catfish, the adult contains more fat than the juvenile species but the reverse was observed for Bonga shad (Table 3). The mean concentrations of OCPs residue in adult and juvenile species are as shown in Table 2 and the most commonly occurring OCP residues were $\mathrm{HCB}$, HCHs, DDD and Dieldrin.

The total concentration of OCPs per unit weight of fish ranged from 2.72-20.57 ppm, with the highest concentration detected in tilapia adult. The adult species of fish analyzed contain relatively higher concentration of DDT and its degradation products (DDD and DDE). The total concentrations of HCHs in fish samples analyzed range from 3.27-10.55 ppm, the highest concentration was detected in Tilapia while the lowest concentration was detected in catfish.
DDTs and metabolites were detected in all the fish analysed. Commercial DDT (mixtures of PP DDT, OP DDT, DDE and DDD) are imported into Nigeria and marketed as zerdane, anofex, chlorophenoethane for control of mosquitoes and other insect-borne diseases. The mean concentration of HCB per wet weight of fish range from $0.47-3.26 \mathrm{ppm}$, (highest concentration detected in Tilapia species) while the mean concentration (per wet weight) of dieldrin and transnonachlor range from $0.02-1.78$ and $0.01-0.56$ ppm respectively. $\mathrm{HCB}$ is widely used as a solvent in pesticides, fungicides and disinfectant in soaps, it is also formed as an industrial by-product in chlorination processes (waste water treatment and wood preservative). Transnonachlor is one of the major constituents of the insecticide. Chlordane, aldrin and dieldrin are widely used in seed preservation to prevent (or stop) growth of weevils. A higher concentration of OCPs was detected in tilapia. Tilapias are middle to top feeders while catfish species are bottom to middle feeders. 


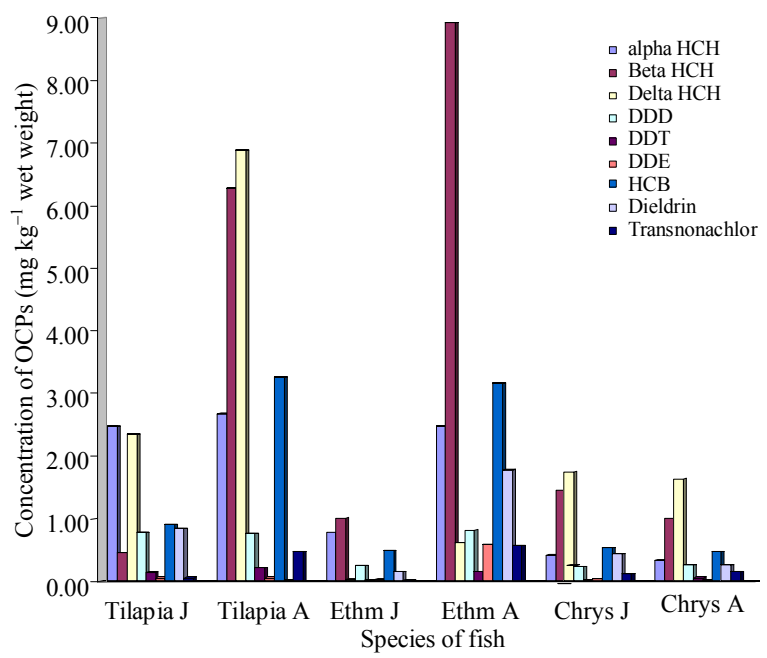

Fig. 1: Mean concentration of OCPs $\left(\mathrm{mg} \mathrm{kg}^{-1}\right.$ wet weight)

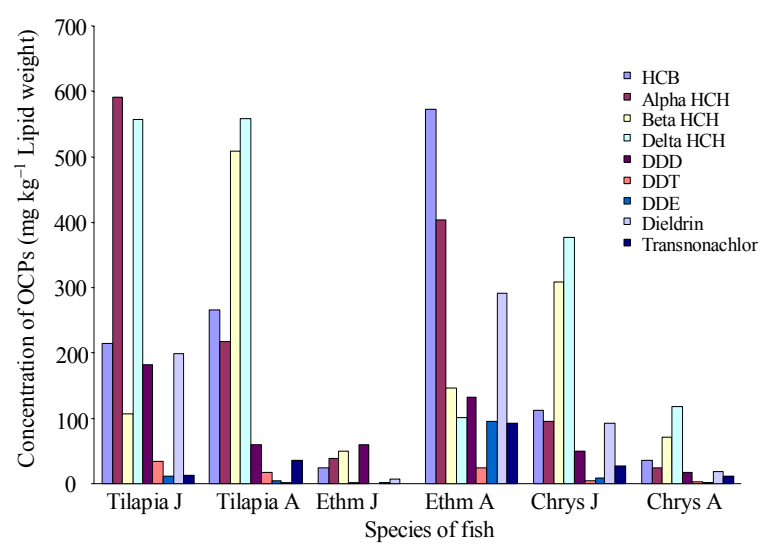

Fig. 2: Mean concentration of OCPs ( $\mathrm{mg} \mathrm{kg}^{-1}$ Lipid weight)

The variation in concentration of OCPs detected in fish species could be attributed to differences in feeding habit and metabolic characteristics of the fish species. Tilapia is primarily an herbivorous cichlidae, its diet is dominated by phytoplankton (Chlrophyllcea, Cyanophycea and Englenophycea) or benthic algae, the African catfish represents the most common species in the aquatic ecosystem and feeds on insects (namely chiromidae) and detritus while bonga shad feeds on detritus, phytoplankton and sand grains depending on the size.

Previous studies indicated that the concentration of OCPs detected in fish samples were higher than those detected in water samples from the same river ${ }^{[2]}$ this is attributed to the fact that pesticides being lipophilic reside and accumulate in fatty tissue, by gaining entrance into fish by ingestion, dermal absorption and respiration $^{[18]}$, the chemicals bioaccumulate in fish until they are caught and eventually eaten by humans.

In Nigeria, the detection of OCPs in some fresh water fish samples have been reported. The concentrations of OCPs in these samples were in ppb range as shown: DDE 2.0-30.0 $\mathrm{ng} \mathrm{g}^{-1}$; DDD 2.0-60.0 $\mathrm{ng} \mathrm{g}^{-1}$; DDT 3.0-18.0 $\mathrm{ng} \mathrm{g}^{-1}$; HCB 9.0-130.0 $\mathrm{ng} \mathrm{g}^{-1}$ and $\mathrm{HCH}$ 0.2-5.0 $\mathrm{ng} \mathrm{g}^{-1}$.

The detection and quantitation of OCPs in South Eastern Nigeria have also been reported, the concentration ranges were $\mathrm{HCH}$ 0.2-7.4 $\mathrm{ng} \mathrm{g}^{-1}$; DDE 0$4.2 \mathrm{ng} \mathrm{g}^{-1}$ and DDD $0-8 \mathrm{ng} \mathrm{g}^{-1[19]}$. The concentrations of OCPs detected in fish samples in this study are much higher. They are also higher when compared to Federal Environmental Protection Agency (FEPA) allowable limit of $<0.01 \mathrm{ppm}$.

In Africa, including Nigeria, rapid urbanization as well as severe pest problems, weeds, rodents, locust, grain eating birds have increased reliance on the use of pesticides. OCPs are a cheap form of insecticides and are widely used. Also co-disposal of industrial, domestic and medical waste in open dumps has contributed immensely to pollution menace in the region. The public awareness on health hazards and risks associated with pesticides are also relatively low in Africa, hence the need for continuous monitoring of xenobiotic pollutants such as OCPs in marine water and biota such as fish.

\section{REFERENCES}

1. Ademoroti, C.M.A., 1996. Environment chemistry and Toxicology. Foludex Press Ltd. Ibadan, pp: 79-208.

2. Ize-Iyamu O.K., I.O. Abia and P.A. Egwakhide, 2007. Concentrations of residues from organochlorine pesticide in water and fish from some rivers in Edo State, Nigeria. Int. J. Physical Sci., 2: 237-241.

3. Mott, L. and K. Snyder, 1987. Pesticide Alert. A Guide to Pesticide in Fruits and Vegetables. Natural Resources Defence Council Sierra Club Books, San Francisco.

4. Tanabe, S., H. Iwata and R. Tatsukwa, 1994. Global contamination by persistent organochlorine and their ecotoxicological impact on marine mammals. Sc. Total Environ., 154: 163-177.

5. Bouman, H., A. Coetzee, C.H.J. Schutte, 1990. Environment and health implication of DDTcontaminated fish from the pongolo flood plain. J. Afr., 104: 275-286. 
6. Brassow, H.L., K. Baumann and G. Lehnert, 1981. Occupational exposure to hexachlorocyclohexane II. Health conditions of chronically exposed workers. Int. Arch Occup. Environ. Health, 48: 81-87.

7. Olea, N., P. Pazos and J. Exposito, 1998. Inadvertent exposure to xenoestrogens. Eur. J. Cancer Prev., 7: 17-23.

8. Winter, C., 1992. Dietary pesticide risk assessment. Rev. Environ Contam. Toxicol., 127: 23-67.

9. Saxena, M.C., M.K.J. Siddique, A.K. Bhargava, C.R. Krishina Murti and D. Kutty, 1981. Placenta transfer of pesticides in humans. Arch Toxicol., 48: 127-134.

10. Caldas, E.D, R.L.C. Coelho, K.R. Souza, S.C. Siba, 1999. Organochlorine pesticides in water sediment and fish of paranoa lake of Brasilia. Brazil Bull. Environ. Contam Toxicol., 62: 199206.

11. Osibanjo, O., 1994. Review of chlorinated hydrocarbon substances in African aquatic environment . F.A.O Fish Rep., 502: 37-45.

12. Atumar, S. and D. Okor, 1985. Gas chromatographic determination of penta chlorophenol in human blood and urine. Bull. Environ. Contain. Tocicol., 35: 406.

13. Osibanjo, O. and A. Adeyeye, 1995. OCPs residues increase. Toxicology, 54: 460-465.
14. Unyimandu, J.P. and Udochu, 2002. Comparative studies of organochlorine and PCBs in fish from the Lagos lagoon, River Elber Saar. J. Agric. Biotech. Environ., 4: 14-17

15. Simundic, B., V. Jakovlic, V. Tadevic and Poznavanje Robe, 1994. Foodstuff and Food Technology Basics in Croatian. Rijeka: Tiskara Rijeka, pp: 326-345.

16. Anyakora, C.A., K.A. Ogbeche, P. Palmer and H. Coker, 2005. Determination of polynuclear aromatic hydrocarbons in the marine samples of siokolo fishing settlement. J. Chromatograp., 1073: 323-330.

17. Anyakora, C.A, K.A. Ogbeche, J. Unyimadu, K. Olayinka, R, Alani and B. Alo, 2004. Determination of polynuclear Aromatic hydrocarbons in the water sample of the lagos lagoon. Nigerian J. Pharmacy, 35: 35-39.

18. Gold-Bouchot, G., T. Silva-Herrera, O. ZapataPerez, 1995. Organochlorine pesticides residue concentrations in biota and sediments from Rio palizada, mexico. Bull. Environ. Contam Toxicol., 54: 554-556.

19. Osibanjo, O. and Bamgbose, 1990. Review of chlorinated substance in marine fish and shellfish of Nigeria. Marine Pollut. Bull., 21: 581-586. 